\title{
The Impact of Explicit Integrated Strategies Instruction on IELTS Applicants' Listening Comprehension
}

\author{
Jahanbakhsh Nikoopour \\ Islamic Azad University, Tehran North Branch, Iran \\ Roozbeh Kargar Moakhar \\ Islamic Azad University, Tehran North Branch, Iran \\ Nadimeh Esfandiari \\ Islamic Azad University, Tehran North Branch, Iran
}

\begin{abstract}
Listeners in a foreign language will not be able to activate the full range of strategies available to a native speaker. Because of variables such as language proficiency, motivation, age, aptitude and the like, they will be at various stages of approximation to full competence. One way to eliminate the obstacles to efficient listening comprehension is strategy instruction. The present study attempted to explore the impact of the explicit instruction of cognitive and memory strategies on IELTS candidates' listening comprehension. The sample consisted of 88 adult male/female EFL learners who attended IELTS preparation classes regularly, and were randomly assigned into three groups. Two groups were as experimental groups, in which eight memory and cognitive strategies were taught explicitly, whereas the third group did not benefit from the explicit instruction of strategies. The analysis of the data showed that the experimental groups outperformed the control group in listening, but the difference between the two experimental groups was not statistically significant. In fact, in both groups in which cognitive or memory strategies were taught explicitly, the mean scores in listening comprehension did not prove to be significant. In further analysis, the applicants' gender did not make a difference in listening comprehension.
\end{abstract}

Index Terms - explicit integrated strategies instruction, memory/cognitive strategies, listening comprehension

\section{INTRODUCTION}

The role of learners and learning strategies has been emphasized in effective learning. The instruction of strategies has been recommended by different scholars because using strategies is an important factor in successful language learning (Dreyer \& Nel, 2003; Oxford, Crookall, Cohen, Lavine, Nyikos, \& Sutter, 1990).

The traditional approaches to the teaching of listening are not effective. In such approaches, listeners review the vocabulary, listen to the text, get an idea of it, and try to answer the questions. In fact, when listeners are expected to listen to a sample, and answer the questions related to it, they are not learning how to listen, but rather they are being tested to see whether they would comprehend the text or not. In teaching learners how to listen, some researchers emphasized strategy instruction (Carrell, 1998; Klingner \& Vaughn, 2000).

Although listening had not been paid much attention in the past, it remains one of the most important skills in language learning in EFL/ESL contexts (Berne, 1998; Clement, 2007; Oxford, 1993; Rubin, 1994).The first step to acquire a second or foreign language is listening comprehension (Liu, 2009). In fact, listening is the first encounter with the target language for non-native speakers when they are exposed to it (Berne, 2004). Although it is important for language learners to develop listening ability in real interaction, we seldom teach them to learn how to listen effectively (Berne, 2004; Vandergrift, 2007).

In the past decades, listening was defined as the listeners' abilities to listen to recorded samples, and be able to answer the questions, without having been instructed any strategies, skills, and techniques to help them complete such tasks (Field, 1998). No textbook was for teaching listening in a second language until the 1970s. It was assumed that through practice, listeners would automatically develop their abilities to comprehend the spoken texts. That is, listeners while being exposed to oral language would develop listening skills through repetition and imitation (Clement, 2007). However, in recent years, many researchers (Carrier, 2003; Berne, 2004; Chamot, 2004; Clement, 2007; Liu, 2009; Graham, Santos, \& Vanderplank, 2011) indicated that the focus has shifted to the development and use of language learning strategies.

Language learning strategies are the conscious thoughts and actions that learners take to accomplish a learning goal (Chamot, 2004). Strategies in listening comprehension are classified into three categories: metacognitive, cognitive, and socio-affective strategies due to the level or type of processing. According to O'Malley and Chamot (1990), 
metacognitive strategies involve planning for learning, monitoring of one's comprehension or production, thinking about the learning process while it is taking place, and assessing an activity when it is accomplished. Cognitive strategies are limited to certain learning activities and involve direct manipulation of the learning material. Socioaffective strategies involve social-mediating activities and are more concerned with interaction with others.

A set of memory and cognitive strategies have been examined in the present study. Oxford (1990) classified these two categories into some distinct strategies. Memory strategies are such as semantic mapping, using keywords, structured reviewing, using mechanical techniques, grouping, associating or elaborating, placing new words into a context, and using imagery. Cognitive strategies are such as translating, analyzing expressions, getting the idea quickly, taking notes, recombining, highlighting, summarizing, and transferring. From among memory and cognitive strategies, these eight strategies were selected to be instructed to IELTS candidates due to practicality reason. These strategies were taught during IELTS preparation course and then integrated by the participants while listening to samples.

\section{Modes of Strategy Instruction}

Regarding strategies instruction, two issues have been put forward (O’Malley \& Chamot, 1990). One was to decide whether to teach strategies through embedded instruction or through explicit instruction. The second issue was to decide whether to teach strategy in a separate way or integrated with classroom instruction.

In embedded strategy instruction, learners are guided by the teacher through getting involved in activities and materials while not being consciously aware of the use and benefits of a certain strategy. By contrast, in explicit strategy instruction, learners get informed of the value and purpose of a certain strategy, and are taught consciously how to use that strategy in a new context (O'Malley \& Chamot, 1990).

Taking the second issue into account, the researchers who advocate integrated strategy instruction claim that integrating strategy training into students' learning activities enables them to apply the strategies in real life situations and transfer them to other tasks and activities (Chamot, et al., 1999; Kendall \& Khuon, 2006; Oxford, 2002; Zhang, 2008). However, the advocates of separate instruction find two faults with integrated strategy instruction; first, after the instruction period, learners cannot apply strategies to other new tasks, and second, all language teachers cannot be trained to have integrated strategies instruction in their classes $(\mathrm{Gu}, 1996)$. Following explicit instruction of strategies, Chamot (2004) claimed that language teachers should integrate instruction into their regular course work, rather than providing a separate strategy course.

While there has been some challenge between the embedded and explicit instruction, explicit instruction was proposed by some researchers (O’Malley \& Chamot, 1990; Cohen, 1998; Oxford, 2002). As O'Malley and Chamot (1990) claimed "early research on training learning strategies following the embedded approach found little transfer of training to new tasks" (p.153). In line with these two researchers, other scholars (Ozeki, 2000; Carrier, 2003; Shen, 2003; Clement, 2007) focused on explicit strategy instruction, which has shown to be useful in maintaining strategy use over time and using strategies for novel tasks in new contexts.

\section{Studies on Strategy Instruction}

Studies done on successful language learners (DeFillipis, 1980; Laviosa, 1991a \& 1991b; Murphy, 1985; O'Malley, Chamot, \& Kupper 1989; Rost \& Ross 1991; Vandergrift 1992) explored a number of cognitive and metacognitive strategies that listeners use. As Derry and Murphy (1986) maintain cognitive strategies are behaviors, techniques, or actions used by learners to acquire knowledge or skill, or to tackle the problems they encounter. Such strategies are elaborating, inferencing, predicting listening to the known, and visualization. Metacognitive strategies are the supervision that learners have on their learning process, the control they have on their learning process. Such strategies are functional planning, monitoring, reality testing, self-assessing, evaluating, and improving their learning approaches (Rubin, 1990). There is a consensus among researchers that successful language learners use strategies. Murphy (1985) claims that successful language learners use strategies flexibly depending on the situation, and O'Malley, Chamot and Kupper (1989) believe that they use self-monitoring strategy.

According to Laviosa (1991a), "the efficiency or inefficiency of any particular strategy employed appears to depend not only on the listeners' L2 knowledge, but mainly on individual differences in perceiving the problems and on their ability to employ strategies and manage the use of a variety of strategies" (p.109). Scholar believe that it is not just the sequence of strategies which makes a distinction between expert and novice language learners, but the way they use self-management to define tasks, perform effectively, select the strategies and evaluate their effectiveness (Vann \& Abraham 1990; Chamot \& O'Malley, 1994).

In a longitudinal study, Thompson and Rubin (1996) examined the impact of cognitive and metacognitive strategy instruction on 36 college level L2 learners' listening comprehension based on 15 hours of video instruction. In the experimental group, the participants were taught to develop cognitive and metacognitive strategies in the form of a treatment, while in the control group, the participants watched videos to initiate some speaking and writing activities. The results of the final video test indicated that the experimental group performed significantly higher than the control group, whereas in the audio test the two groups showed no difference. Their study as the first longitudinal, classroombased strategy instruction, regardless of its short research period and relatively insufficient results, showed the importance of listening strategy instruction.

In another study in Taiwan, Chen (2009) explored the effect of strategy instruction on listening performance in a regular college EFL class over a 14 week span with 31 non-English major students. The focus of the study was to teach 
metacognitive, cognitive, and socio-affective listening strategies integrated to an extension of the listening curriculum. Within each strategy category, the researcher detected selective strategies that had been proven effective in the literature. The results revealed that the participants acquired higher awareness and control in their strategy use. In each specific category of strategy, there were some important findings. Inferencing, replay, and understanding each word were among the most common cognitive strategies used by students. Regarding metacognitive strategies, although learners used various strategies predominantly during the treatment at different periods, as a whole, they used metacognitive strategies fairly equally. In socio-affective strategies, low and average proficiency language learners showed a great increase in their use.

\section{METHOD}

\section{A. Participants}

Some IELTS applicants (about 100) were given a language proficiency test to check for their homogeneity before presenting the treatment. Those participants whose scores fell one standard deviation below or above the mean $(88$ applicants) were selected and included in the final sample based on non-random availability sampling. They were from Afarinesh Language Institute in Tehran. Also, gender was included as a moderator variable; thus, both male and female candidates were selected. Three groups of participants were included in the study. The first group (30 learners) received explicit instruction on memory strategies (the first experimental group), while the other one (32 learners) received explicit instruction on cognitive strategies (the second experimental group) and the third group (26 learners) used the conventional prevalent techniques for practicing IELTS listening comprehension (the control group).

\section{B. Materials}

The teaching materials employed were 16 IELTS listening samples used in three groups. However, in the first group, the listening samples were taught while instructing eight memory strategies explicitly as the treatment of the study. In the second experimental group, the episodes were taught along with instructing eight cognitive strategies. In the control group, the conventional techniques were used for teaching IELTS listening samples. The point was that all the passages were chosen randomly from the IELTS passages included in IELTS sample tests.

\section{Instruments}

Three instruments were used to collect data. The first instrument used was a language proficiency test to help the researcher select homogenous participants for the study. The second instrument was an IELTS listening pre-test, which was administered before presenting the treatment since the candidates were expected to be homogeneous in listening comprehension as well. The third instrument was an identical IELTS listening comprehension test used as a posttest which was administered to the participants after the treatment to see if the treatment would have any effect on the participants' performance in listening comprehension.

\section{Procedure}

At first, 100 IELTS candidates from Afarinesh Institute were randomly selected. Having selected the homogeneous candidates through using a proficiency test, the researcher assigned the participants randomly into three groups. Then, a listening comprehension pretest was administered to the three groups to account for their homogeneity in listening comprehension before the treatment.

The first group was taught eight memory strategies, which took around 16 sessions. Eight memory strategies of ' grouping', 'associating or elaborating', 'placing new words into a context', 'using imagery', 'semantic mapping', 'using keywords', 'structured reviewing', and 'using mechanical techniques '(Oxford, 1990 cited in Brown, 2007, p.141) were instructed to the candidates explicitly. They learned each strategy in one session, and practiced to implement the strategies while they practiced IELTS listening samples during the treatment. The researchers provided the candidates with an awareness of the strategy because the purpose was not to follow "blind training" of the strategy, whereas they were expected to learn the strategy explicitly, and be able to use it practically in different contexts. Depending on the theme of listening episodes, the researchers helped the candidates to apply the strategies they had learned where they could find it useful and effective.

The second group, however, received eight cognitive strategies in the second experimental group. Eight cognitive strategies of 'highlighting', 'summarizing', 'taking notes', 'transferring', 'translating', 'analyzing expressions', 'getting the idea quickly', and 'recombining' (Oxford, 1990 cited in Brown, 2007, p.141) were instructed to them explicitly. Like the first experimental group, these candidates learned each strategy in a session, but practiced them spirally during the 16 sessions while practicing IELTS listening samples. The participants were taught to learn each single cognitive strategy explicitly every session, and be able to implement it in the new situations. In any possible context, in which they could find useful or effective, they were encouraged to use the strategies autonomously.

The third group, that is, the control group received the conventional methods which are usual in IELTS preparation programs. Regarding the listening comprehension, they attempted to listen to the text and answer the questions afterward. The researcher was made sure that in the control group, the prevalent current method in teaching listening 
comprehension was utilized. They did not practice memory and/or cognitive strategies as their counterparts in the two experimental groups did.

As the next step, a listening posttest was administered to the three groups to measure their listening comprehension after the treatment. The listening comprehension test was an identical test compared with the pretest in order to minimize the practice effect. All the participants in the three groups were given the same time restriction to take the tests based on a uniform procedure to eliminate any fluctuation due to the test rubrics. The test scores were analyzed in order to detect any probable difference between the three groups.

\section{RESULTS}

\section{A. The Analysis of the Pretests}

At first, it was necessary to check the homogeneity of the participants in language proficiency in general and listening comprehension in particular. The three groups showed not to be significantly different based on the ANOVA results.

TABLE 1.

ANOVA RESULTS FOR THE PRETESTS

\begin{tabular}{lllllll}
\multicolumn{7}{c}{ ANOVA RESULTS FOR THE PRETESTS } \\
\hline \multirow{3}{*}{ LPT } & Sum of Squares & df & Mean Square & F & Sig. \\
& Between Groups & 39.79 & 2 & 19.90 & 1.499 & .229 \\
& Within Groups & 1128.21 & 85 & 13.27 & & .523 \\
& Total & 1168.00 & 87 & & .653 & \\
\multirow{3}{*}{ Listening1 } & Between Groups & 3.38 & 2 & 1.69 & & \\
& Within Groups & 220.35 & 85 & 2.59 & & \\
& Total & 223.74 & 87 & & & \\
\hline
\end{tabular}

Before starting the treatment, the researcher had to check for the homogeneity of the participants in listening comprehension. The researcher used ANOVA and detected that the difference between the three groups was not statistically significant. Thus, the researcher could start presenting the treatment to the candidates. The treatment was of two types: teaching eight memory strategies to one experimental group, and teaching eight cognitive strategies to the other experimental group.

\section{B. The Analysis of the Listening Post- Test}

The present study focused on the explicit instruction of eight memory and eight cognitive strategies in the two experimental groups, while in the control group, the participants were exposed to the same oral content and practiced the traditional or prevalent techniques used for listening comprehension. After finishing the treatment in 16 sessions, the researcher compared the listening comprehension mean scores of the three groups to detect whether they have shown significant difference or not. ANOVA was used and the results revealed that the difference among the groups was statistically significant.

TABLE 2.

ANOVA RESULTS FOR LISTENING POSTTEST

\begin{tabular}{llllll}
\hline \multicolumn{7}{c}{ ANOVA RESULTS FOR LISTENING POSTTEST } \\
\hline Between Groups & Sum of Squares & df & Mean Square & F & Sig. \\
Within Groups & 195.12 & 2 & 97.56 & 29.747 & .000 \\
Total & 278.78 & 85 & 3.28 & & \\
\hline
\end{tabular}

ANOVA showed the difference between the groups is significant. To detect where the significant difference lies, there is a need to apply a Post Hoc Multiple Comparison for the same analysis.

TABLE 3.

A Post Hoc (Multiple COMPARISONS) ANALysis FOR THE LisTENING POSTTEST

\begin{tabular}{|c|c|c|c|c|c|c|}
\hline \multirow[t]{2}{*}{ (I) groups } & \multirow[t]{2}{*}{$(\mathrm{J})$ groups } & \multirow{2}{*}{$\begin{array}{l}\text { Mean Difference } \\
(\mathrm{I}-\mathrm{J})\end{array}$} & \multirow[t]{2}{*}{ Std. Error } & \multirow[t]{2}{*}{ Sig. } & \multicolumn{2}{|c|}{ 95\% Confidence Interval } \\
\hline & & & & & Lower Bound & Upper Bound \\
\hline \multirow{2}{*}{ Exp group(memory strategies) } & Exp group(cognitive strategies) & -.766 & .460 & .099 & -1.68 & 0.14 \\
\hline & Control group & 2.791 & .485 & .000 & 1.82 & 3.75 \\
\hline \multirow{2}{*}{ Exp group(cognitive strategies) } & Exp group(memory strategies) & .766 & .460 & .099 & -.14 & 1.68 \\
\hline & Control group & 3.557 & .478 & .000 & 2.60 & 4.50 \\
\hline \multirow{2}{*}{ Control group } & Exp group(memory strategies) & -2.791 & .485 & .000 & -3.75 & -1.82 \\
\hline & Exp group(cognitive strategies) & -3.557 & .478 & .000 & -4.50 & -2.60 \\
\hline
\end{tabular}

Based on the Post Hoc comparison, the difference between the control group and the two experimental groups is statistically significant. It is concluded that teaching memory and cognitive strategies in the experimental groups made a significant difference in the candidates' listening comprehension in the posttest; that is, the treatment or the explicit instruction of memory and cognitive strategies was effective.

However, the difference between the two experimental groups was not statistically significant. That is, the two different types of strategies had similar effect on the participants' listening comprehension. It is concluded that strategies 
instruction, whether memory or cognitive, could improve the IELTS candidates' listening comprehension though not being significantly different from one another.

The role of gender in the study was also investigated. The aim was to detect whether male and female candidates show difference in their listening comprehension. To see whether gender could make a difference in listening, the researcher utilized one-way ANOVA.

TABLE 6.

ANOVA RESULTS FOR LISTENING PRE- AND POSTTEST BY GENDER

\begin{tabular}{|c|c|c|c|c|c|c|}
\hline & & Sum of Squares & df & Mean Square & $\mathrm{F}$ & Sig. \\
\hline \multirow{3}{*}{ Listening1 } & Between Groups & 3.59 & 1 & 3.59 & 1.402 & .240 \\
\hline & Within Groups & 220.15 & 86 & 2.56 & & \\
\hline & Total & 223.74 & 87 & & & \\
\hline \multirow{3}{*}{ Listening2 } & Between Groups & 1.27 & 1 & 1.27 & .232 & .631 \\
\hline & Within Groups & 472.63 & 86 & 5.49 & & \\
\hline & Total & 473.90 & 87 & & & \\
\hline
\end{tabular}

The results of ANOVA revealed that male and female candidates were not statistically different in their listening pretest and posttest. The values computed for each of the four measurements (sig=.240, and 0.631) are higher than 0.05 ; therefore, the difference is not statistically significant.

\section{DISCUSSION}

The first experimental group in which eight memory strategies were being taught outperformed the control group in which the learners used to practice the texts traditionally. Also, the other experimental group in which the learners practiced eight cognitive strategies during the treatment had also better listeners. The two experimental groups showed an improvement in their listening comprehension, but the inter-group difference was not statistically significant. It seemed that the two types of strategies, that is, memory and cognitive ones influenced the candidates' listening comprehension similarly. These two types of Strategies-Based Instruction (SBI) proved to be similarly decisive in IELTS candidates' performance in listening comprehension in comparison to the control group. Based on the test results, female and male EFL learners performed similarly in IELTS listening comprehension tests.

The findings of the present study confirmed that ample evidence links strategy instruction to improved performance in learners' language (Derry \& Murphy 1986). It is concluded that strategy instruction has been linked to better reading (Hosenfeld, Arnold, Kirchofer, Laciura, \& Wilson, 1981), improved speaking (O'Malley, Chamot \& Walker, 1987) and more effective vocabulary acquisition (Cohen \& Horowitz, 2002).

The present study put emphasis on explicit strategies instruction, as proposed by Harris (2003), who compared four training models - O'Malley and Chamot (1990), Oxford (1990), Chamot et al. (1999) and Grenfell and Harris (1999). There are also additional models, such as in Macaro (2001) and Cohen and Horowitz (2002). There is clearly very considerable consensus among researchers and educators to strategy training. As Duffy (1993) states, listening strategies refer to those remedies which are used to solve problems that learners face in grasping meaning from the text. There is a wide range of listening strategies, from some micro text-based strategies, such as guessing the meaning of a word from context, to more conceptual macro strategies, such as subsuming the incoming information, or personalizing what they listened to.

The findings of the present study confirmed the results of the studies done by Swain, (2000) who suggested that if strategy training involves verbalizing the strategies employed together with opportunity to use the strategies explicitly in the context of communicative activity, it can be effective, and Kitajima (1997), who suggested that students could successfully learn to use a strategy presented in an instruction program and that improved comprehension might be achieved at the same time, although a causal link could not be shown, and Carrell, Pharis, and Liberto (1989) who investigated the impact of two metacognitive strategy approaches on comprehension which showed that both types of intervention improved comprehension.

The results of the present study highlighted the findings of some studies in which Strategies-Based Instruction (SBI) was the concern of the researchers, such as Kusiak (2001) who carried out a metacognitive strategy-based instruction program, and proved how these two variables- metacognition and comprehension- were related to L2 language competence. Also, a complex Strategy-Based Instruction program was carried out by Dreyer and Nel (2003), in which they investigated the impact of metacognitive strategies instruction on two groups of students, and found that while learning to use metacognitive strategies, both successful and at-risk students showed a significant difference in their comprehension.

The findings of the present study are different from those previous studies, in which the explicit instruction of strategies was not suggested for EFL learners. Regarding teaching learner strategies, there is not complete uniformity among the researchers. It is clear that teaching learner strategies is not universally successful. Concerning the effectiveness of strategy training, Macaro (2006) claims that it is hard to come up with stable conclusion because of a lack of agreement in the intervention packages and how learning outcome is assessed. Or in an experiment done by Bialystok (1983b), the strategy training proved to be less effective in promoting either comprehension or vocabulary acquisition than the other two conditions in his study. Also, O'Malley and Chamot (1990) doing a study on the effects of 
strategy training on the learners' performance on a listening and a speaking task, found no significant differences among the experimental groups. They found that a group taught 'functional planning' (a metacognitive strategy) outperformed both the control group and the other experimental group taught 'cooperation' (a social/affective strategy) in the speaking task. There was no effect for strategy training in the listening task. In a study, on the impact of strategy-based instruction on speaking in a foreign language, Cohen and Horowitz (2002) found that the experimental group outperformed the control group on only one of the three oral tasks in the posttest.

Listening is described as an active process in all recent studies, in which listeners select and interpret information elicited from the oral discourse. Listeners attempt to understand what is going on and what the speaker expresses (Clark \& Clark, 1977; Mendelsohn \& Rubin, 1995; Richards, 1983). Language teachers attempt to help listeners integrate their world knowledge and linguistic knowledge to be able to process the information through listening process. According to Mendelsohn \& Rubin (1995), language teachers should feel responsible to help their students develop listening comprehension through using strategies not merely providing a chance for them to listen.

The concern of previous studies was to investigate whether listening strategy instruction through using a quantitative method has any impact on listening comprehension. However, recently listening strategy instruction has been carried out in various contexts ranging from child language learners to adult learners, from EFL contexts to ESL contexts, and from primary school level to college level. Although these studies were subject to small sample size and short research period, their general findings confirmed that listening strategy training will result in better understanding and use of strategies and better listening comprehension. Future researchers are expected to investigate Strategy-Based Instruction (SBI) from a triangulated view; that is, from teachers' effectiveness, from experts' perception, and from learners' actual and autonomous use of listening strategies.

\section{REFERENCES}

[1] Berne, J. E. (1998). Examining the relationship between L2 listening research, pedagogical theory, and practice. Foreign Language Annals, 31(2), 169-190.

[2] Berne, J. E. (2004). Listening comprehension strategies: A review of the literature. Foreign Language Annals, 37(4), 521-531.

[3] Bialystok, E. (1983). Some factors in the selection and implementation of communication strategies. In C. Faerch \& G. Kasper (Eds.), Strategies in interlanguage communication (pp. 100-118). London: Longman.

[4] Carrell, P. L. (1998). Can reading strategies be successfully taught? Australian Review of Applied Linguistics, 21(1), 1-20.

[5] Carrell, P. L., Pharis, B. G., \& Liberto, J. C. (1989). Metacognitive strategy training for ESL reading. TESOL Quarterly, 23 (1), 647-678.

[6] Carrier, K. A. (2003). Improving high school English language learners second language listening through strategy instruction. Bilingual Research Journal, 27(3), 383-408.

[7] Chamot, A. U. \& O’Malley, J. (1994). The CALLA handbook: Implementing the cognitive academic language learning approach. Reading, MA: Addison-Wesley.

[8] Chamot, A. U., Barnhardt, S., El-Dinary, P. B., \& Robbins, J. (1999). The learning strategies handbook. White Plains, NY: Addison Wesley Longman.

[9] Chamot, A.U. (2004). Issues in language learning strategy research and teaching. Electronic Journal of Foreign Language Teaching, 1(1), 14-26.

[10] Chen, A. H. (2009). Listening strategy instruction: Exploring Taiwanese college students' strategy development. Asian EFL Journal, 11(2), 54-85.

[11] Clark, H. H., \& Clark, E. V. (1977). Psychology and language: An introduction to psycholinguists. New York: Harcourt Brace Jovanovich.

[12] Clement, J. (2007). The impact of teaching explicit listening strategies to adult intermediate- and advanced-level ESL university students. Retrieved from ProQuest Dissertations and Theses. (UMI No. 3253098).

[13] Cohen, A.D., \& Horowitz, R. (2002). What should teachers know about bilingual learners and the reading process? In J.H. Sullivan (Ed.), Literacy and the second language learner (pp. 29-54). Greenwich, CT: Information Age Publishing.

[14] Cohen, A. D. (1998). Strategies in learning and using a second language. London: Longman.

[15] DeFillipis, D. A. (1980). A Study of the Listening Strategies used by Skillful and Unskillful College French Students in Aural Comprehension. Unpublished PhD dissertation, University of Pittsburgh (cited in Rubin, 1994).

[16] Derry, S. J., \& Murphy, D. A. (1986). Designing systems that train learning ability: From theory to practice. Review of educational research, 56(1), 1-39.

[17] Dreyer, C., \& Nel, C. (2003). Teaching reading strategies and reading comprehension within a technology-enhanced learning environment. System, 31(3), 349-365.

[18] Duffy, G. G. (1993). Teachers' progress toward becoming expert strategy teachers. The Elementary School Journal, 94(2), 109120.

[19] Graham, S., Santos, D., \& Vanderplank, R. (2011). Exploring the relationship between listening development and strategy use. Language Teaching Research, 15(4), 435-456.

[20] Grenfell, M., \& Harris, V. (1999). Modern language and learning strategies. London: Routledge.

[21] Gu, P. Y. (1996). Robin Hood in SLA: What has the learning strategy researcher taught us? Asian Journal of English Language Teaching, 6 (1), 1-29.

[22] Harris, A. (2003). Teacher leadership as distributed leadership: heresy, fantasy or possibility?. School Leadership \& Management, 23(3), 313-324.

[23] Hosenfeld, C., Arnold, V., Kirchofer, J., Laciura, J., \& Wilson, L. (1981). Second language reading: A curricular sequence for teaching reading strategies. Foreign Language Annals, 14(5), 415-422. 
[24] Kendall, J., \& Khuon, O. (2006). Writing sense: Integrated reading and writing lessons for English language learners, K-8. Portland, ME: Stenhouse Publishers.

[25] Kitajima, R. (1997). Referential strategy training for second language reading comprehension of Japanese texts. Foreign Language Annals, 30(1), 84-97.

[26] Klingner, J. K., \& Vaughn, S. (2000). The helping behaviors of fifth graders while using collaborative strategic reading during ESL content classes. TESOL Quarterly, 34(1), 69-98.

[27] Kusiak, M. (2001). The effect of metacognitive strategy training on reading comprehension and metacognitive knowledge. EUROSLA Yearbook, 1(1), 255-274.

[28] Laviosa, F. (1991a). A preliminary investigation of the listening problem-solving processes and strategies of five advanced learners of Italian as a second language. Doctoral dissertation, State University of New York at Buffalo.

[29] Laviosa, F. (1991b). An Investigation of the Listening Strategies of Advanced Learners of Italian as a Second Language. Paper presented at the Conference on Bridging Theory and Practice in the Foreign Language Classroom (Baltimore, MD, October 18 20, 1991).

[30] Liu, Y. C. (2009). The utilization of listening strategies in the development of listening comprehension among skilled and lessskilled non-native English speakers at the college level. Retrieved from ProQuest Dissertations and Theses. (UMI No.3400780)

[31] Macaro, E. (2001). Analyzing student teachers' codeswitching in foreign language classrooms: Theories and decision making. The Modern Language Journal, 85(4), 531-548.

[32] Macaro, E. (2001). Learning strategies in second and foreign language classrooms. London \& New York: Continuum.

[33] Macaro, E. (2006). Strategies for language learning and for language use: Revising the theoretical framework. The Modern Language Journal, 90(3), 320-337.

[34] Mendelsohn, D. J., \& Rubin, J. (1995). A guide for the teaching of second language listening (pp. 132-150). San Diego, CA: Dominie Press.

[35] Murphy, J. M. (1985). An investigation into the listening strategies of ESL college students. (ERIC Document Reproduction Service No. ED 278 275).

[36] Oxford, R. L. (1990). Language learning strategies: What every teacher should know. New York: Newbury House.

[37] Oxford, R.L. (1993). Instructional implications of gender differences in second/foreign language learning styles and strategies. Applied Language Learning 4(1), 65-94

[38] Oxford, R. L. (2002). Language learning strategies in a nutshell: Update and ESL suggestions. In J.C. Richards \& W.A. Renandya. Methodology in language teaching; An anthology of current practice. Cambridge: Cambridge University Press, 2002, 124-132.

[39] Oxford, R.L., Crookall, D., Cohen, A., Lavine, R., Nyikos, M., and Sutter, W. (1990). Strategy training for language learners: Six situational case studies and a training model. Foreign Language Annals, 22(3), 197-216.

[40] Ozeki, N. (2000). Listening strategy instruction for female EFL college students in Japan. Tokyo: Macmillan Language House.

[41] O’Malley, J. M., \& Chamot, A. U. (1990). Learning strategies in second language acquisition. New York: Cambridge University Press.

[42] O'Malley, J. M., Chamot, A. U., \& Walker, C. (1987). Some applications of cognitive theory to second language acquisition. Studies in Second Language Acquisition, 9(3), 287-306.

[43] O’Malley, J. M., Chamot, A. U., \& Küpper, L. (1989). Listening comprehension strategies in second language acquisition. Applied Linguistics, 10(4), 418-437.

[44] Reid, J. M. (1998). Understanding learning styles in the second language classroom. Upper Saddle River, NJ: Prentice Hall Regents.

[45] Richards, J. C. (1983). Listening comprehension: Approach, design, procedure. TESOL Quarterly, 17(2), 219-240.

[46] Rost, M., \& Ross, S. (1991). Learner use of strategies in interaction: Typology teach ability. Language Learning, 41(2), 235268.

[47] Rubin, J. (1990b). Improving foreign language listening comprehension. In J.E. Alatis (Ed.), Georgetown University Round Table on Languages and Linguistics 1990: Linguistics, language teaching, and language acquisition, the interdependence of theory, practice, and research (pp. 309-316). Washington, DC: Georgetown University Press.

[48] Rubin, J. (1994). A review of second language listening comprehension research. The Modern Language Journal, 78(2), 199221.

[49] Swain, M. (2000). The output hypothesis and beyond: Mediating acquisition through collaborative dialogue. In Lantolf, J.P. (Ed). Sociocultural Theory and Second Language Learning. Oxford University Press, Oxford, 2000, 97-114.

[50] Shen, H. J. (2003). The role of explicit instruction in ESL/EFL reading. Foreign Language Annals, 36(3), 424-433.

[51] Thompson, I., \& Rubin, J. (1996). Can strategy instruction improve listening comprehension? Foreign Language Annals, 29(3), 331-342.

[52] Vann, R. J., \& Abraham, R. G. (1990). Strategies of unsuccessful language learners. TESOL Quarterly, 24(2), 177-198.

[53] Vandergrift, L. (1992). The comprehension strategies of second language (French) listeners. Alberta, Canada: University of Alberta.

[54] Vandergrift, L. (2007). Recent developments in second and foreign language listening comprehension research. Language Teaching, 40(3), 191-210.

[55] Zhang, L. J. (2008). Constructivist pedagogy in strategic reading instruction: Exploring pathways to learner development in the English as a second language (ESL) classroom. Instructional Science, 36(2), 89-116. 


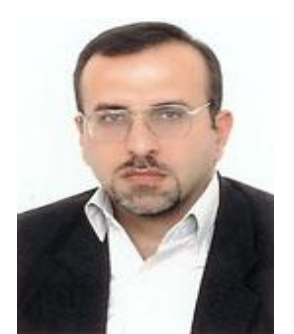

Jahanbakhsh Nikoopour is an assistant professor in Applied Linguistics at Islamic Azad University, North Tehran Branch. He was born in Tehran in 1966. He finished his BA studies in TESOL at University for Teacher Education in Tehran in 1990, then accomplished his MA studies at Tarbiat Modarres University in Tehran in 1994. He got his Ph.D. from Islamic Azad University, Science and Research Campus, Tehran, Iran in 2005. His dissertation was "The Wash back Effect of the University Entrance Examinations on EFL Education in Iran."

Dr. Nikoopour is a faculty member in TEFL Department at Islamic Azad University, North Tehran Branch. He has published several papers in domestic and international journals so far. He is also a member of the Editorial Board for some national and international journals related to TESOL. His research interests include language assessment, teacher education, language learning strategies, CALL and learner variables.

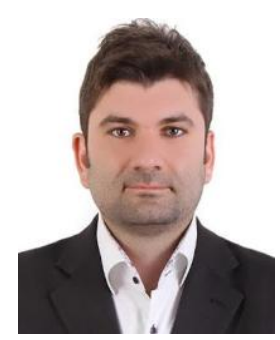

Roozbeh Kargar Moakhar is a Ph.D. candidate at Islamic Azad University, North Tehran Branch in TEFL. He was born in 1981 in Tehran. He finished his BS studies in Electronic Engineering at Islamic Azad University, Central Tehran Branch in 2006. He studied in TEFL at the MA level from 2014 to 2016 at Islamic Azad University, North Tehran Branch. He has been teaching English at various levels for about ten years, and he has been involved in IELTS preparation programs in Afarinesh English language institute for the last ten years. He has professionally developed in his teaching career. He has presented some papers in national conferences, and published some papers in computer sciences. His research interests include teacher education, language assessment, learner variables, and CALL.

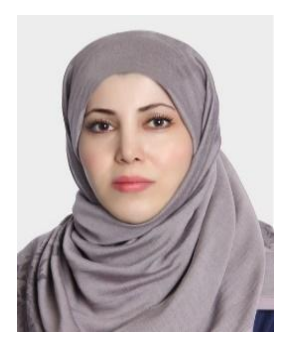

Nadimeh Esfandiari is an MA holder in TESOL, graduated from Islamic Azad University, North Tehran Branch. She was born in 1976 in Tehran. She finished her BA studies in English Translation Studies in 2011, and accomplished her MA studies in TEFL in 2014. She has been teaching English at various levels for about ten years. She has shown great interest and creativity in her teaching career. She has presented some papers in national and international conferences, and published some papers in national and international journals. Her research interests include language assessment, factors influencing language learning, teacher professional development. 